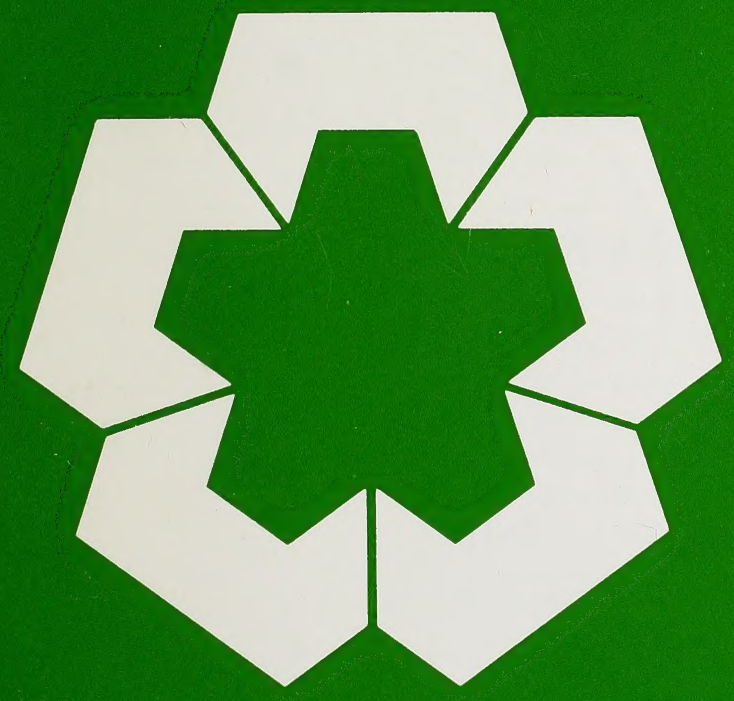

AN INVESTIGATION INTO THE USE OF BIOLOGICAL AGENTS FOR THE CONTROL OF AQUATIC PLANT GROWTH IN IRRIGATION SYSTEMS IN ALBERTA RMD Report 87/40

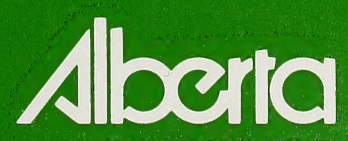

ENVIRONMENT 


\section{RESEARCH MANAGEMENT DIVISION EMBLEM}

The Emblem represents the interdisciplinary and holistic nature of the Division's environmental research programs. Each of the five sections of the symbol represent comprehensive programs on air, water, land, humans and their constant interaction. The sections converge to form a cohesive chain, characteristic of an effective research organization. This cohesive bonding makes the sections blossom into the environment in the form of a flower - an Albertan wild rose. 


\section{AN INVESTIGATION INTO THE USE OF BIOLOGICAL AGENTS FOR THE CONTROL OF AQUATIC PLANT GROWTH IN IRRIGATION SYSTEMS IN ALBERTA}

RESEARCH MANAGEMENT DIVISION Alberta Environment 
Digitized by the Internet Archive in 2016

https://archive.org/details/investigationint00alle 
For information on reports published by the Research Management Division, contact:

Research Management Division

Publications Office

14th Floor, Standard Life Centre

10405 Jasper Avenue

Edmonton, Alberta

T5J 3 N4

(403) $427-3946$

This report may be cited as:

Allen, E. Ashley Dale. 1987. An investigation into the use of biological agents for the control of aquatic plant growth in irrigation systems in Alberta. Prep. for Alberta Environment, Research Management Division. RMD Report 87/40. 26 pp. 



\title{
AN INVESTIGATION INTO THE USE OF BIOLOGICAL AGENTS FOR THE CONTROL OF AQUATIC PLANT GROWTH IN IRRIGATION SYSTEM IN ALBERTA
}

\author{
by
}

E. ASHLEY DALE ALLEN

\author{
for \\ RESEARCH MANAGEMENT DIVISION \\ Alberta Environment
}

RMD Report $87 / 40$ 
The report is made available as a public service. The Department of Environment neither approves nor disagrees with the conclusions expressed herein, which is the possibility of the author. 


\section{EXECUTIVE SUMMARY}

Aquatic plants growing in Alberta irrigation canals cause a serious problem by reducing the flow of water. Four species growing completely beneath the water have been identified which cause most of the flow problems. These are: Potamogeton pectinatus, $\underline{P}$. richardsonii, $\underline{P}$. vaginatus, and Alisma graminium. All of these plants are common and are present in most areas of the province. Control of these species in irrigation canals has largely been carried out using herbicides which kill the top parts of the plants resulting in only short-term improvement to flow. Some of the herbicides are toxic to fish and the cost of chemicals and their application is high.

Prolific growth of aquatic plants such as water hyacinth, Eurasian watermilfoil, and salvania in other areas of the world has resulted in the search for, and development of, biological control techniques. A number of these have been quite successful like the use of insects for the control of water hyacinth and salvania. Some of these biological control techniques might be successfully adapted for use in the management of the problem species in the Alberta irrigation system.

Plant-eating fish, particularly the white amur have been used in the United States, Europe, and Russia. In moderately warm waters these fish eat large quantities of $\mathrm{plant}$ material but they are difficult to control.

Insects have been successfully used to control a number of floatingleaved species but at the present time no insects are known to prey to a significant degree on the canal plants in Alberta.

A number of pathogens, mostly fungi, have been isolated and described. They are weakly pathogenic and attack most readily, the plants damaged by insects. Pathogens effective against plants in Alberta canals would have to be sought from a variety of locations and sources, then isolated and tested.

A native species, the Slender spikerush (Eleocharis acicularis), has been used to displace and prevent and re-establishment of other species. 
It forms a dense sod which prevents other plants from rooting in the bottom. There is some indication that spikerush may release substances which inhibit the growth of other species. Slender spikerush is found in many parts of the province including some irrigation ditches. The usefulness of spikerush to displace other aquatic plants should be examined in a range of current velocities and sediment loads. Biological control techniques have the potential to give longer lasting results than chemicals and may be a possible replacement or compliment to chemical or mechanical harvesting, however the development of any biological technique would require several years of work. 


\section{TABLE OF CONTENTS}

Page

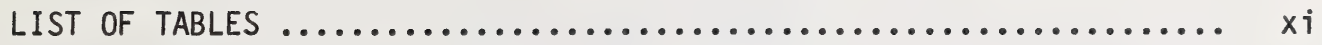

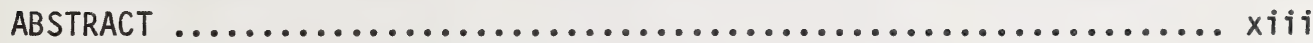

1. INTRODUCTION $\ldots \ldots \ldots \ldots \ldots \ldots \ldots \ldots \ldots \ldots \ldots \ldots \ldots \ldots \ldots \ldots \ldots$

2. THE STREAM ENVIRONMENT $\ldots \ldots \ldots \ldots \ldots \ldots \ldots \ldots \ldots \ldots \ldots \ldots \ldots$

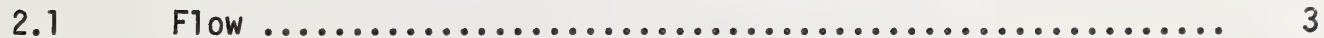

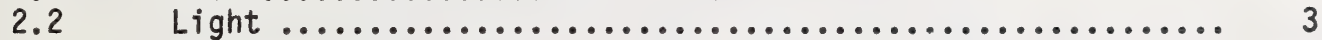

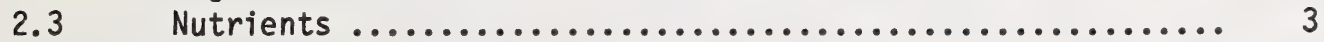

3. NUISANCE SPECIES IN ALBERTA IRRIGATION CANALS $\ldots \ldots \ldots \ldots \ldots .5$

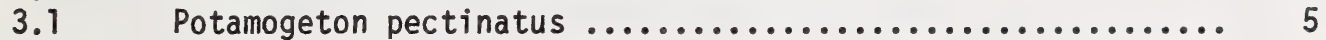

3.2 Potamogeton richardsonii ........................... 5

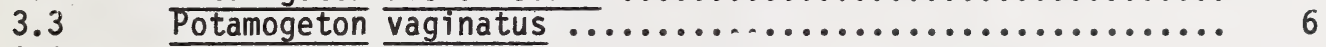

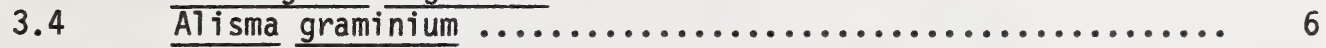

4. GERMINATION OF SEEDS $\ldots \ldots \ldots \ldots \ldots \ldots \ldots \ldots \ldots \ldots \ldots \ldots \ldots \ldots \ldots \ldots \ldots \ldots$

5. BIOLOGICAL CONTROL OF AQUATIC PLANTS ................. 8

5.1 Control by Phytophagous Fishes ...................... 8

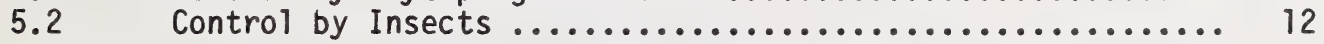

5.3 Replacement of Problem Vegetation by Other Species ....... 13

5.3.1 Biology of Dwarf Spikerush ........................ 14

5.3.2 Propagation of Dwarf Spikerush ..................... 14

5.3.3 Interaction of Dwarf Spikerush with Other Species ....... 15

$5.4 \quad$ Use of Pathogens ................................ 17

5.5 Effects of Drawdown ............................... 19

5.6 Effects of Channel Shape ......................... 19

6. IMPORTATION OF EXOTIC SPECIES $\ldots \ldots \ldots \ldots \ldots \ldots \ldots \ldots \ldots \ldots$

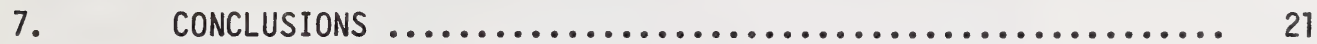

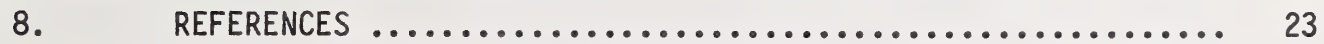


$x i$

\section{LIST OF TABLES}

Page

1. Grazing Preferences of Ctenopharyngodon idella ............ 11 


\section{ABSTRACT}

Four species of aquatic plants are the primary cause of flow reduction in the Alberta irrigation system. They are: Potamogeton pectinatus, $\underline{P}$. richardsonii, $\underline{P}$. vaginatus, and Alisma graminium. They are currently managed with herbicides. Several biological control systems have been used in other areas of the world to reduce the abundance of aquatic plants. Some of these techniques might be adapted for use in Alberta.

Plant-eating fish, particularly the white amur, have been introduced in many areas where they have successfully reduced or eliminated aquatic vegetation. They are relatively non-specific feeders, eating both emergent and submerged species. Many areas have restrictions on the introduction of the fish.

Insects are a more specific control agent. A variety of insects including weevils and leaf-boring flies have been used. Insects have successfully controlled water hyacinth and salvania in tropical areas. No insect species are known to attack the problem species in Alberta.

Several fungi have been isolated which are mildly pathogenic to certain species of aquatic plants including water hyacinth and water milfoil. Plants are most susceptable when they are stressed or damaged by insects or cutting. A search for fungi which are pathogenic to the Alberta potamogetons may produce a potential control agent.

Two species of spikerush (Eleocharis) have been used to displace and prevent the re-establishment of aquatic plants in canals in California. One of these species is native to Alberta and might be successfully used in Alberta canals.

of the several biological control systems described, the use of spikerush and the development of a suitable pathogen bears further investigation. 

1. INTRODUCTION

Aquatic plants rarely attract much attention unless they cause trouble. Unfortunately, there are many instances where these plants do create severe problems for the use of water systems. Both still and moving waters are potential habitats for this group of plants, supplying nutrients and physical support. Rooted plants associated with the aquatic environment occupy three distinct habitats: those that grow almost completely beneath the surface and rise above the surface only to flower (submerged); those that produce aerial leaves that float on the surface or rise above the water surface (floating or amphibious); and those that are rooted in shallow water and grow primarily above the water (emergents). Species from all these groups can cause problems in canals and streams. Emergents such as the reeds and cattails can invade canals from the shoreline, reducing effective width and restricting flow in shallow water, while both submerged and floating-leaved species increase the resistance to flow as well as plugging smaller ditches and culverts when they detach.

Restriction of flow requires the water level at the input end of the canal to be raised to force water through, but this approach is limited by the height of the canal banks. In addition, the presence of plants decreases the velocity of the water to the point where sediment particles fall out, leading to increased rates of sediment deposition. The quantity of aquatic plants can be very large. Westlake (1970) found that annual production in the River Frome in England was 30 to 50 tonnes fresh weight per year on an area of $43 \mathrm{ha}$. In Alberta, submerged aquatic plants have been controlled in the irrigation canals largely with herbicides. There are a number of chemicals which are licenced for use in waters utilized for irrigation or livestock watering. These are: acrolein, diquat, diuron, fenac, and paraquat. Herbicides achieve moderate control, killing the tops of the plants, but their effects are short term and can be toxic to fish, as is acrolein. The almost total reliance on chemical control results in continuing expense and is affected by changes in supply.

The purpose of this report is to examine biological methods for the control of aquatic plants which have been used in other areas of the world and 
which might be adapted for use in Alberta irrigation canals. Good biological control systems are effective and can be self-maintaining. They are often difficult to establish and require very careful study before implementation to ensure that the control agent can be controlled and does not cause damage itself. 


\section{THE STREAM ENVIRONMENT}

The stream environment is more variable then lakes. Water levels fluctuate much more rapidly, appreciable currents may be present, and there is often a sediment load which affects light levels and if heavy, can smother aquatic plants. Three parameters of the stream environment affect the type and quantity of plants that will grow in them.

\subsection{FLOW}

The effect of water movement on plants is primarily mechanical. Plants offer resistance to flow that is determined by the shape and size of the plant. Submerged plants with narrow filiform or highly divided leaves offer less resistance to flow than those with large or entire leaves. The amount of current that a plant can withstand also depends upon the extent of root development and the firmness of the bottom of the water course. Currents (both the velocity and the frequency of spate flows) are an important factor in determining which species will become established or which can resist being torn out of a stream. An extensive treatment of flow on aquatic plants is given by Haslam (1978).

\subsection{LIGHT}

In any aquatic system, the availability of light for photosynthesis greatly influences both the speciation and density of the plant cover. Light is attenuated by water and coloured substances, scattered by suspended particles, and is reflected from the water surface. In flowing water, the sediment load is often very high and light penetrates only a short distance. Although the light requirements of plants vary, an estimation of the lower limit of colonization is given by: $z_{c}=1.4 / K_{\min }$, where $K_{\min }$ is the attentuation coefficient of the least attenuated wavelengths of light (Spence 1975). A description of the light climate in rivers and streams is given by Westlake (1966).

\subsection{NUTRIENTS}

Aquatic plants acquire nutrients from both the water and the sediments; the relative importance of each medium appears to be related to the 
concentrations of available nutrients in both phases. Inorganic carbon in the form of dissolved carbon dioxide and bicarbonate is supplied from the water. Westlake (1967) has shown that photosynthesis rates in Ranunculus pseudofluitans increase up to sixfold in flowing water compared to static conditions, presumably by increasing the rate of carbon supply to the leaves. Flowing systems are able to replenish nutrients taken up by the plants, unlike static systems, which can become limited for some nutrients during the growing season. 
3. NUISANCE SPECIES IN ALBERTA CANALS

The submerged species that cause problems in Alberta irrigation canals, through their overabundant growth, are three pondweed species: Potamogeton pectinatus, Potamogeton richardsonii, Potamogeton vaginatus, and the water plantain Alisma graminium.

The members of the genus Potamogeton (from the Greek potamos - river) are perennials consisting of about 260 species; 81 present in North America and 16 in Alberta. It is a morphologically diverse group of plants that live primarily beneath the water surface. Some species have both submerged and emergent types of leaves. The Potamogeton species listed above are common circumpolar plants and are found widely distributed throughout Alberta. They are found in both still and flowing water.

\subsection{POTAMOGETON PECTINATUS}

The Sago pondweed is a narrow-leaved species with a much-branched growth form, and is found from Florida to northern Alberta and in Europe. It grows in both lakes and streams in saline, brackish, or calcareous waters. It is moderately tolerant to currents, especially if the bottom is not scoured. $\underline{P}$. pectinatus produces seeds on spikes carried above the water surface. Its main method of reproduction is vegetative. Fragments of the plants that include at least a small amount of rhizome are able to root quickly in a new location. In the autumn this species also produces tubers that lie dormant just beneath the surface of the mud. Dormancy is broken by temperatures near freezing enabling them to start active growth in the spring. Haslam (1978) describes $P$. pectinatus as being very tolerant to pollution from sewage and to conditions of high turbidity.

\subsection{POTAMOGETON RICHARDSONII}

Richardson's or Clasping-leaf pondweed is a much-branched species that has sessile leaves 3 to $12 \mathrm{~cm}$ long and 1 to $2 \mathrm{~cm}$ wide and is found from Labrador to Alaska in brackish or hard water. It is found in both lakes and slow-moving streams throughout the province. Seeds are produced on spikes in late summer, but their importance in the proliferation of this species is not 
known. P. richardsonii perenniates from a well-developed rhizome system, and it is also able to spread through fragmentation. It reportedly hybridizes with $\underline{P}$. praelongus, $\underline{P}$. $\underline{i l l i n o e n s i s,} \underline{P}$. gramineus, $\underline{P}$. nodosus, and P. amplifolius (Fernald 1950).

\subsection{POTAMOGETON VAGINATUS}

The Large-sheath pondweed is a large robust plant, much-branched, with narrow filiform leaves and is found from Labrador to Alaska in hard or brackish water.

The stems and leaves are very tough and are able to withstand flowing water but the species is found mostly in lakes, sloughs, and in slow-moving streams. Reproduction is primarily from rhizomes and seeds.

\subsection{ALISMA GRAMINIUM}

Narrow-leaved water-plantain is one of two species of Alisma found in the province, primarily in th south and in a few locations in central Alberta. The plant has long, ribbon-like submerged leaves 5 to $10 \mathrm{~mm}$ wide as well as erect lanceolate emergent leaves. It is found in shallow water in marshy areas, ponds, and in some-slow moving streams. The leaves arise from a bulb-like base, in which form the plant overwinters. Seeds are produced in fairly large numbers. No papers appear to have been published on the biology of this species. The description and distribution of $\underline{A}$. graminium is given in Moss (1983) and in Ogden (1966, 1974). 


\section{GERMINATION OF SEEDS}

The seeds of Potamogeton and Alisma, like those of many other aquatic plants, show strong dormancy. Dormancy prevents their immediate germination when the newly formed seeds are shed into the water or are wetted by waves or rising water. The dormancy is lost over time but germination is often prevented by a tough impermeable seed coat. Germination is initiated when the seed coat is damaged by rotting or mechanical abrasion such as passage through the digestive tract of a water bird. Haag (1983) collected samples of sediments from Lake Wabamun, Alberta in early May and kept them at $19^{\circ} \mathrm{C}$. Seedlings of Potamogeton pectinatus appeared within one week while seedlings of Potamogeton richardsonii took 33 to 37 days to emerge. A second exposure of the sediments to temperatures of $2^{\circ} \mathrm{C}$ to $4^{\circ} \mathrm{C}$ for four months caused further emergence of Potamogeton pectinatus. Haag found that of seven species of Potamogeton found in Lake Wabamun, $\underline{P}$. pectinatus, and $\underline{P}$. $\underline{\text { richardsoni }} \underline{\underline{f}}$ produced the largest number of $\mathrm{plants}$ from the germination of naturally dispersed seeds. Spence (1971) has shown that at least some species of Potamogeton require red 1 ight to break dormancy. 
Aquatic plants have caused severe problems in lakes, reservoirs, and waterways in many parts of the world. The most significant problems have been caused by prolific growths of the water hyacinth, Eichhornia crassipes, in Africa, Florida, and in other tropical areas. The congestion of important waterways by the water hyacinth has resulted in numerous studies aimed at controlling its abundance by biological means. Biological control of this species has been quite successful after over 20 years of research.

\subsection{CONTROL BY PHYTOPHAGOUS FISHES}

Plant eating fish have been used to control aquatic vegetation for many years. There are three species of interest: the silver carp, Hypothalmichthys molitrix; the bighead carp, Aristichthys nobilis; and the white amur or grass carp, Ctenopharyngodon idella. The white amur has been frequently used in Europe, the United States, and the Soviet Union as a means of reducing populations of submerged and emergent plants and as a food fish. Al though called the grass carp, Ctenopharyngodon is not a true carp, but belongs to the minnow family. It originally comes from the Amur River region, which forms the border between the USSR and Manchuria. The fish can reach a weight of $50 \mathrm{~kg}$, can tolerate low oxygen concentrations, and can tolerate temperatures ranging from $0^{\circ} \mathrm{C}$ to $33^{\circ} \mathrm{C}$. The fish feed in mid-water and at the surface and do not appear to disturb the sediments with their feeding activities.

A considerable body of literature on the biology of the white amur exists. A review has recently been published by Pierce (1983). Most of the studies in which the fish has been used as a control for aquatic plants have had positive results, but considerable controversy still exists over its introduction into new areas. In the United States, its importation has been banned in 26 states, a permit for research purposes only is required in 17 states, and licences for its use by private individuals is required in 13 states. It was originally introduced into the United States in Arkansas in 1963, and can now be found in 40 states. It has not been used in Canada. Concern over the use of the white amur for the control of aquatic vegetation 
results largely from fear of it spreading into other areas, the possibility of over-controlling aquatic vegetation, and damaging habitats for other game fish.

The white amur is a river fish that has very specific requirements for reproduction. Spawning outside its natural Chinese rivers is rare but has occurred in the USSR, Japan, and Mexico, as well as the lower Mississippi River system (Conner et al. 1980). Spawning has not been found to occur in western Europe. Spawning temperatures range from $15^{\circ} \mathrm{C}$ to $30^{\circ} \mathrm{C}$ with an optimum of $20^{\circ} \mathrm{C}$ to $22^{\circ} \mathrm{C}$. The eggs have a tendency to sink and must be suspended by currents to keep them oxygenated and free of silt. Stanley et a1. (1978) indicate that currents of 0.6 to $1.5 \mathrm{~m} / \mathrm{s}$ are needed but any current over about $0.8 \mathrm{~m} / \mathrm{s}$ is adequate. The eggs require a minimum of $19^{\circ} \mathrm{C}$ to $20^{\circ} \mathrm{C}$ for development with an optimum temperature range of $22^{\circ} \mathrm{C}$ to $26^{\circ} \mathrm{C}$. The time for hatching depends on water temperature and is about 24 to 30 hours at $25^{\circ} \mathrm{C}$ and 60 hours at $17^{\circ} \mathrm{C}$. Because of the hatching time and current requirements, a length of river determined by the current velocity and temperature is required for successful hatching. At $20^{\circ} \mathrm{C}$ and a velocity of $1.2 \mathrm{~m} / \mathrm{s}$ a river length of $180 \mathrm{~km}$ is needed, but in warmer water at $28^{\circ} \mathrm{C}$ with a velocity of $0.8 \mathrm{~m} / \mathrm{s}$ only $50 \mathrm{~km}$ is required. The river must be well oxygenated and turbid water appears to be preferred for spawning (Stanley et a1. 1978).

The white amur can be a voracious feeder, the amount eaten is dependent upon the water temperature. At temperatures under $10^{\circ} \mathrm{C}$ food intake is very low and may be supplemented by animal material, but above approximately $13^{\circ} \mathrm{C}$ feeding greatly increases. At $20^{\circ} \mathrm{C}$ the fish may eat about $50 \%$ of their weight per day increasing their intake to $100 \%$ of body weight at $22^{\circ} \mathrm{C}$ (Opuszynski 1972). Because of a short digestive tract, only about $50 \%$ of ingested food is metabolized, and considerable amounts of partly digested material containing nitrogen and phosphorus are excreted. Some authors indicate that this might cause increased eutrophication, resulting in algal blooms (Stroganov 1963; Prowse 1969). However, Terrell (1975) and Lembi et a1. (1978) did not find any increase in phytoplankton productivity. Boyle (1979) and Mitzner (1978) found a reduction of nutrients in ponds where white amur had been introduced after two years. 
The white amur shows some degree of $\mathrm{plant}$ preference in its diet. It uses pharyngeal teeth for mastication and the young adults prefer leaves to stems. Older fish become less selective and will eat tougher material, including emergent plants growing in shallow water. Cross (1969) has compiled a list of grazing preferences from a number of sources (Table 1), but considerable variation occurs.

When introduced into ponds and lakes, the white amur has proven to be very effective way of reducing the quantity of aquatic vegetation. Terrell and Terrell (1975) found that one-year-old fish introduced into three Georgia ponds reduced the amount of vegetation by $79 \%$ to $89 \%$ in one year, and in one pond where the fish were not removed, vegetation was completely eliminated in the second year. Leslie et a1. (1983) found that white amur stocked at a rate of $50 /$ ha effectively controlled Hvdrilla and Potamogeton illinoensis, while Eurasian watermilfoil (Myriophyllum spicatum) was eliminated, only returning after three to six years. Some increase in nitrogen and phosphorus as well as an increase in turbidity occurred, while chlorophyll-a in the water decreased, indicating that there was no increase in the production of phytoplankton.

Van Zon (1977) examined the relative cost-effectiveness of using the white amur. Mechanical control of weeds in ditches costs about 2700 Dutch florins/ha, control using paraquat and dalapon cost $1300 \mathrm{Dfl} / \mathrm{ha}$, while white amur cost $600 \mathrm{Dfl} / \mathrm{ha}$ per year which included construction of fences. The cost of stocking the fish was not given. Van Zon indicated that the use of this fish in waterways and canals in the Netherlands is a viable alternative to chemical control where the water is used for irrigation, drinking, and recreation. An ongoing research program is being carried out in Holland by the National Board of Agricultural Research (as of 1977).

The white amur has been used in Russia for plant control and as a food fish in a number of widely separated areas in the country. Negonovskaya (1981) indicates that both breeding and feeding rates drop with increasing 1atitude. Reproduction occurred in the tributaries to the south end of the Aral Sea, but not in the north end, which is cooler. Negonovskaya (1981) states that at latitudes over $45^{\circ} \mathrm{N}$, cooler water temperatures and a fish fauna that includes more predators, such as pike, slow the growth rate of the introduced fish and reduce their numbers. Stocking with fish over one year 
Table 1. Grazing preferences of Ctenopharyngodon idella. ${ }^{a}$

Canadian Pondweed

Hornwort

Stonewort

Lesser duckweed

Broad-leaved pondweed

Ivy-leaved duckweed

Eurasian watermilfoil

Sago pondweed

Great reedmace (Cattails)

Common reed

Common rush

Black sedge

Frogbit

Watercress

Shiny pondweed

Sedge
Elodea canadensis

Ceratophyllum demersum

Chara spp.

Lemna minor

Potemogeton natans

Lemna trisulca

Myriophyllum spicatum

Potamogeton pectinatus

Typha latifolia

Phragmites communis

Juncus effusus

Carex nigra

Hydrocharis morsus-ranae

Nasturtium officinale

Potamogeton lucens

Carex pseudocyperus

aFrom Cross 1969 
old which weigh 250 to $350 \mathrm{~g}$ (over $45 \mathrm{~cm}$ in length), increases the number of survivors.

Federenko and Fraser (1978) reviewed some of the literature on the white amur, but dismissed its use in British Columbia lakes because of possible risks to the indigenous fauna and the remote chance of breeding.

The use of a sterile triploid hybrid resulting from the cross of Ctenopharyngodon eggs with sperm from the bighead carp Aristichthys nobilis, has been tried in Russia and they have been bred commercially in the United States in Arkansas. Osborne (1982) found that in Florida, the hybrid showed slower growth, lower feeding rates, higher mortality, and an increased incidence of abnormalities. In addition, it may be necessary to test each fish to ensure that it is truly triploid.

An extensive five-year study, funded jointly by the Washington State Department of Ecology, and the U.S. Fish and Wildlife Service has been initiated to evaluate the impact of white amur and the sterile hybrid. The study will examine methods of distinguishing between diploid and triploid fish, effectiveness of the triploid, stocking densities, and the effects of the fish on the other species (Pauley et al. 1985).

\subsection{CONTROL BY INSECTS}

The use of insects for controlling aquatic plants has concentrated on the most prominant nuisance species: water hyacinth, salvania, hydrilla, alligatorweed and Eurasian watermilfoil. Significant progress has been made in controlling water hyacinth in several parts of the world, especially in the White Nile. Two weevils, Neochetina eichhorniae and Neochetina bruchi, found in Argentina, and a moth Sameodes albiguttalis, were introduced in the area in 1978 to 1979. N. eichhorniae has become established between Juba and Kosti, and has caused damage to $100 \%$ of the plants at the northern end of the range (Anonymous 1985). Insects in this instance have proven to be very effective control agent, and have significantly reduced the amount of plant material reaching the Jeba Aulia Dam near Khartoum. The two weevils have also been introduced and established in the southeastern United States, where they have dramatically lowered growth, reduced plant size and biomass, 
and have occasionally caused the total collapse of water hyacinth stands (Center and Jones 1984).

Because water hyacinth is a floating plant, there are probably more insect species that will attack it. Totally submerged plants are only vulnerable to attack by insects which are capable of living under water or within the airspaces in the stems.

Hydrilla (Hydrilla verticilliata) has become a severe problem in the southeastern part of the United States since its introduction about 25 years ago. Weevils from the genus Bagous, as well as leaf mining and stem boring flies in the genus Hydrilla, and an aquatic Parapoynx have shown potential for control and have been allowed into the United States under quarantine for further investigation (Balcunias 1984).

The use of plant predators for controlling nuisance plants occurring as mixtures requires species that do not show great selectivity or preference for one plant over another. The selective removal of only one or two species from an area will usually allow other opportunistic species to invade and these may be even more difficult to control Large-scale predation of aquatic plants is uncommon, resulting in the accumulation of large amounts of plant biomass which is utilized by insect larvae and other organisms only after the plants begin to senesce or die. Ostrowsky and Zettler (1986) found as many as 55 alkaloids in a survey of 15 aquatic plants, including nine species of Potamogeton. Although the alkaloid content of the plants was generally low, the concentrations were high enough to be pharmacologically active, and these could act as herbivore deterrents. Other compounds may be present in some aquatic plants which lowers their palatability.

\subsection{REPLACEMENT OF PROBLEM VEGETATION BY OTHER SPECIES}

The flow of water in canals may be improved by replacing tall stands of vegetation with dense growths of shorter plants that will form a mat or sod on the bottom. The slender spikerush (Eleocharis acicularis) was observed to invade and displace other species in some irrigation canals and reservoirs in California (Yeo and Fisher 1970). The plant tolerated fluctuating water levels and was able to displace other aquatic plants such as Elodea and Potamogeton from the canals. Although it does not appear to have been widely 
used as a colonizer in canals outside California, this species or a related species, the dwarf spikerush (E. coloradoensis) might be useful in preventing larger plants from becoming established in waterways.

Yeo and Thurston (1984) examined the effects of dwarf spikerush on the growth of a number of aquatic plants grown in outdoor tubs that each had an area of $0.21 \mathrm{~m}^{2}$. The aquatic weeds were established for four weeks, after which tubers of dwarf spikerush were added at a density of $4000 / \mathrm{m}^{2}$. The reduction of growth of the test species from greatest to least was:

Zannichellia palustris Horned pondweed

Elodea nuttallii Western waterweed

Elodea canadensis Canada waterweed

Hydrilla verticillata Hydrilla

Potamogeton nodosus American pondweed

Myriophyllum spicatum Eurasian watermilfoil

Spikerush also was able to reduce the number of tubers formed by sago pondweed by over $50 \%$.

\subsubsection{Biology of Dwarf Spikerush}

Eleocharis coloradoensis belongs to the Cyperaceae, the sedge family. It consists of a rosette of spike-like culms (photosynthetic stems), which issue from a crown. It spreads vegetatively by rhizomes growing horizontally just below the soil surface, forming new rosettes at 0.5 to $3 \mathrm{~cm}$ intervals. This growth habit enables a single plant to cover a considerable area with a dense network of $\mathrm{plants,} \mathrm{forming} \mathrm{a} \mathrm{sod} \mathrm{that} \mathrm{stabilizes} \mathrm{the} \mathrm{soil}$ and keeps the plants well anchored in flowing water. Tubers are also formed. These act as an overwintering stage and can help to spread the plant when they are dislodged by currents or waterfowl. Seeds are produced in fairly large numbers in inflourescences formed at the tips of the culms.

\subsubsection{Propagation of Dwarf Spikerush}

Yeo (1980) measured the rate of spread of spikerush started from seeds, tubers, and rosettes. The plants grew fastest in July, when the water temperatures reached $26^{\circ} \mathrm{C}$. Growth occurred along a straight line, with new rosettes coming off in pairs at right angles to the main axis. After six 
months, the plants started from tubers had expanded to $150 \mathrm{~cm}$, while those started from rosettes reached $127 \mathrm{~cm}$, and those from seeds, $99 \mathrm{~cm}$. The number of rosettes produced were 87,66 , and 49 , respectively.

The dwarf spikerush appears to be easy to propagate, and seed production is abundant. Yeo and Dow (1978) found that seeds are best stored after drying slightly without using heat. Dormancy was broken by exposing the seeds to $37^{\circ} \mathrm{C}$ for 21 days, achieving a germination rate of $80 \%$. Seeds stored under water did not perform as well. Tubers al so grew better if dried slightly, with over $70 \%$ surviving exposures to $-15^{\circ} \mathrm{C}$.

\subsubsection{Interaction of Dwarf Spikerush with Other Species}

Dwarf spikerush has been described as being allelopathic (Frank and Dechoretz 1980). Allelopathy is an antagonistic relationship between species, where one species reduces competition from other organisms by affecting the growth of its competitor through the production of chemicals. Such compounds produced by a plant can inhibit the germination of seeds and the growth of other plants in its vicinity. True allelopathy is difficult to prove conclusively because competition for light, nutrients, and water also affects growth.

Indications that dwarf spikerush may be allelopathic arise from its ability to displace other species such as Potamogeton. During a three-day study, Frank and Deschoretz (1980) grew dwarf spikerush in pots and inserted tubers of $\underline{P}$. nodosus and $\underline{P}$. pectinatus into the sod. After four months, the number of new Potamogeton plants growing in the presence of spikerush was oniy one third the number growing without spikerush. Rhizomes were formed by Potamogeton, but no new shoots were formed.

In a second experiment, two species of Potamogeton were supplied daily with water taken from cultures of spikerush. After 16 weeks, the number of new $\underline{P}$. nodosus plants was about one-half that of the control, and $\underline{P}$. pectinatus growth was only one-third that of the control. The control was watered with tap water. Frank and Deschoretz felt that the change in nutrient concentrations between the treatment and the control was insufficient to cause the difference in growth and concluded that some inhibitory substance produced by the spikerush was responsible. 
The use of spikerush as a cover for canal bottoms has several advantages. Five species of spikerush are found in Alberta and one of these Eleocharis acicularis, produces short culns 3 to $12 \mathrm{~cm}$ high. It is found in wet places throughout Alberta, including the extreme south, therefore there would not be the problems associated with the introduction of an exotic plant species. Because of its rhizomatous growth habit and the production of both seeds and tubers, its propagation should be relatively easy. Yeo and Fisher (1970), used E. acicularis in their earlier work and established it in a California canal where the water levels fluctuated from 0.76 to $0.91 \mathrm{~m}$ with a current of $0.11 \mathrm{~m} / \mathrm{s}$. Yeo described a site at a depth of 3 to $4.5 \mathrm{~m}$ on a lake bottom that was colonized over a two-year period, during which, spikerush appeared and expanded to cover an area of 4 ha. Bates et al. (1985) state that Eleocharis acicularis is able to tolerate a depth of inundation of $0.5 \mathrm{~m}$ during the summer in the Tennessee Valley but must be dewatered in the late summer or early autumn to improve rhizome development and extension.

The dense growth achieved by spikerush forms a sod that can stabilize the bottom soil and reduce the success of re-invasion by other species. There are indications that spikerush is more resistant to some herbicides. This would allow the use of a combination of spikerush and chemicals to control aquatic plants. There are problems that may limit the use of spikerush in Alberta. It may not be able to establish and spread in Alberta canals and to withstand the currents and silt loads that are encountered.

One other species, the stonewart Chara, is capable of invading areas from which other aquatic plants have been removed. It also has a low growth profile and can be fairly effective in preventing re-invasion. However, in the author's experience, Chara does not grow well in flowing water, is not tolerant to siltation, and does not appear to occur in lakes where algal blooms regularly occur. It is therefore not suitable for canal use.

If spikerush could be established in canals, it might be a very effective way of reducing the frictional resistance to flow caused by larger aquatic plants. An examination of the performance of the two smaller species of spikerush, Eleocharis coloradoensis and E. acicularis, in a range of canal types, would be useful in assessing the utility of these plants in Alberta. 


\subsection{USE OF PATHOGENS}

Pathogenic agents have been implicated as the cause of sudden declines in aquatic plant populations such as the reduction of Eurasian watermilfoil in Chesapeake Bay (Bayley et al. 1568). Since that time, a number of investigators have searched for pathogens that show specificity for some nuisance species, particularly water hyacinth and watermilfoil. The techniques used are quite simple. Plants are collected from as many areas as possible, especially where plants show evidence of damage by disease. Portions of these plants are surface sterilized and pieces of the internal tissues are excised and placed on a range of nutrient media to culture whatever fungi or bacteria may be present. Once mono-specific cultures are obtained, healthy plants are infected either by adding the agent to the water or by inserting material directly into a wound in the steli. Plants are then allowed to develop the disease, and the pathogen is re-isolated from infected plants as final proof of its pathogenicity.

Most of the pathogenic agents isolated so far have been fungi. Freeman (1971) lists pathogens for a number of aquatic plants including seven for water hyacinths, six for hydrilla, and one for watermilfoil. The fungus Cerospora rodmanii, described by Conway (1976), was sprayed on water hyacinth, producing a high rate of infection and damage. The disease spread rapidly to 1.7 ha from an inoculation site of $65 \mathrm{~m}^{2}$, and in subsequent tests Conway and Freeman (1976) were able to infect plants in an area of over 100 ha in Florida. A greater effect of the fungus was achieved when it was combined with another fungus Acremonium zonatum or insects like the noctuid moth Arzama densa and the weevil Neochetina eichhorniae.

Andrews et a1. $(1981,1982)$ isolated and described a fungus Fusarium sporotrichiodes from Eurasian watermilfoil in Lake Mendota, Wisconsin. The cultured fungus was inoculated as a suspension of conidia (asexual spores) into watermilfoil plants that had been wounded by puncturing with a needle to imitate insect damage. In flask cultures, $100 \%$ of the plants were infected within two weeks of inoculation but no infection occurred in plants that had not been injured. If a wound was allowed to heal for five days before inoculation, the infection rate dropped to $31 \%$. Infected plants developed symptoms of apical chlorosis, becoming yellow-orange in colour. Stems also 
showed local necrosis at the site of infection, which expanded to fill the entire internode. Such internocies often became weak enough to collapse. Further spread of the fungus was prevented by the diaphragms which form a barrier across the nodes. Conidia germinated on the surface of the plant to form a mycelium but it was unable to penetrate an intact epidermis. Andrews et al. (ibid.) felt that the poor ability of tre fungus to invade a plant greatly reduces its usefulness as a biocontrol agent, but wounding by mechanical harvesters or insects may be helpful in increasing the rate of infection.

Andrews et a1. (1982) isolated a second fungus, Acremonium curvulum, which was found in $6 \%$ to $94 \%$ of the watermilfoil plants sampled from nine lakes. The fungus could be isolated from many plants that had been surface sterilized from excized tissues indicating that Acremonium can live endophytically in healthy non-stressed plants. Plants that were stressed either died or gradually lost leaves from the base of the stems toward the tips. Plants often recovered by growing new tips.

Another fungus, Pythium carolinianum, from parrotfeather (Myriophyllum brasiliense), a species related to Eurasian watermilfoil, has been isolated by Bernhardt and Duniway (1984). The fungus was found in wilting and dying plants in a California drainage ditch, where the vegetation showed necrosis of the stems and damage to the roots. The fungus was isolated and mass cultured. Outdoor containers planted with parrotfeather were infected by adding a suspension containing the fungus. After about nine weeks the infected plants had soft, black, stunted roots. The fresh weight of infected plants was about $20 \%$ to $33 \%$ less than the controls, but the infected plants were not killed. Plants which were inoculated by mechanically inserting spores wilted and collapsed within six days. Other isolates of Pythium carolinianum were obtained by Bernhardt and Duniway from Myriophyllum spicatum, Potamogeton pectinatus, Potamogeton crispus, and Potamogeton nodosus but the pathogenicity of these isolates or their effects on these other plant species does not appear to have been investigated.

Pathogens have been found for aquatic plants that constitute major nuisances, but a search for pathogens effective against the species that cause problems in Alberta waterways has not been carried out. It is quite possible 
that pathogens for these species exist, and an examination of plants for disease-causing fungi isolated are not virulently pathogenic to actively growing, healthy plants. Damage by mechanical harvesting or insects can enhance their effectiveness.

\subsection{EFFECTS OF DRAWDOWN}

The removal of water from canals for part of the year has some beneficial effects on reducing the numbers of plants. Without water the plants are exposed to freezing temperatures and dessication which can kill the shoot and rhizome-root systems. Susceptibility to drawdown varies among species. Those species that form tubers or root deeply are not as affected as those which normally overwinter as turions or winter buds. The removal of competing species by drawdown may actualiy increase the numbers of resistant plants. Because overwinter drawdown is routinely carried out in Alberta irrigation canals, those plants that are the least affected have been selected and now constitute the major nuisance species. Nichols (1974) compiled a list of species from several sources, arranging them according to their susceptability to drawdown. There were many inconsistencies in the described plant responses.

\subsection{EFFECTS OF CHANNEL SHAPE}

Canals might be constructed so that they do not provide a good habitat for plants. Digging canals so that they have steep sides and greater depth can reduce the amount of light available for plant growth, particularly if there is some turbidity in the water. The steep banks, especially if trees are grown along the edge, will cause shading of the water in narrow channels and increase the stability of the banks. This approach is limited by the nature of the soils forming the canal walls. Weak, sandy soils will not hold steep slopes and the planting of trees along the edge can drop considerable amounts of debris into the canal. 
6. IMPORTATION OF EXOTIC SPECIES

Most of the biological control techniques described require the importation and release of non-native species of plants and animals. Because nearly all of the major nuisance-causing species of aquatic plants that have been studied are themselves exotics, the search for predators and pathogens tends to be more productive in the area of the plant's origin.

The importation of the white arnur has been opposed or banned in many areas and it has not been used in Canada because of concerns over potential competition with native species. It also has a tendency to migrate to other areas with the possibility of introducing exotic fish parasites and diseases.

Importation of species and the movement of indigenous species are controlled by the Biological Programs Section of the Plant Health Division of Agriculture Canada. Pathogens of humans and other vertebrate animals are regulated by the Laboratory Centre for Disease Control, Health Protection Branch, Health and Welfare Canada and by the Health of Animals Directorate, Agriculture Canada. Some of the relevant groups that are controlled under the Plant Quarantine Act requiring import permits are: any organism associated with plants; bacteria associated with plants; fungi associated with plants; insects; mites; molluscs (terrestrial species); and plant viruses.

Applications for a permit must include:

1. Applicant's name and address;

2. Applicant's telephone number;

3. Name and address of foreign exporter;

4. Country of origin of the organism;

5. Scientific name of the organism including species, genus, and family;

6. Purpose of importation;

7. Intended mode of transportation; and

8. Place of entry into Canada.

Application forms are available from the Permit Office, Plant Health Division, Agriculture Canada (Ottawa, KIA OC6) and from district offices of the Operations Directorate, Food Production and Inspection Branch, Agriculture Canada. 
7. CONCLUSIONS

Canals, like most other aquatic habitats in Alberta provide conditions that are conducive to the abundant growth of aquatic plants. The control of aquatic plant growth is imperative in order to maintain flow through the canals. Several biological control techniques have been used in other areas, some showing considerable success. Of these, the use of insects for the control of water hyacinth and salvania has been the most spectacular. Both of these are floating-leaved species, which may be more susceptible to insect attack than completely submerged forms. A combination of insects that damage the plants and fungi that can readily enter the plant through the insect-damaged areas has shown some promise in controlling watermilfoil. By extension, a search for pathogens specific for the Potamogeton species that are causing problems in the Alberta canals may yield an organism suitable as a biological control agent. Such as approach would take some time to develop; both for the search for, and the evaluation of, potential pathogens.

The use of plant-eating fish, particularly the white amur, offers a control technique with the potential for more immediate use. Considerable experience with this fish has been acquired in the United States, Europe, and the Soviet Union. The adult fish are not very selective feeders and can readily control weed growth in both lakes and canals. With careful control of stocking levels, it should be possible to prevent the fish from completely removing the plants from an area. Its specialized requirements for breeding greatly reduces the possibility of the fish proliferating on its own, and the development of a sterile hybrid lowers this risk even more. There is a risk that imported white amur could bring a number of parasites into the province which could then affect other fish. There is also the problem of keeping the fish in the areas where they are intended to control weed growth. Fences of barriers to prevent their kigration would be required and the effectiveness of these, especially at times of high water levels, would be questionable. The effectiveness of the white amur in Alberta should be examined by introducing the fish into isolated weed-filled ponds where feeding rates, growth, and food preferences, could be examined.

The native Alberta spikerush, Eleocharis acicularis and the dwarf spikerush, E. coloradoensis, both used by Yeo in California, have shown 
promise in displacing other species and preventing their re-establishment. E. acicularis can grow in some Alberta canals and a program to evaluate its potential as a control agent would be useful. Its ease of establishment, rate of spread, and ability to prevent the invasion of the nuisance species should be examined. Because E. acicularis is a native plant, there would not be the problem of introducing an exotic species.

Any biological control technique would require some time for development and testing. Such techniques have been used successfully on several species elsewhere in the world, but those plants causing problems in Alberta canals have not been as intensively studied, leaving a number of possibilities open for investigation. 
8. REFERENCES CITED

Andrews, J.H. and E.P. Hecht. 1981. Evidence for pathogenicity of Fusarium sporotriciodes to Eurasian watermilfoil (Myriophyllum spicatum). Canadian Journal of Botany 50:1069-1077.

Andrews, J.H., E.P. Hecht, and S. Bashirion. 1982. Association between the fungus Acremonium curvulum and Eurasian watermilfoil, Myriophyllum spicatum. Canadian Journat of Botany 60:1216-1221.

Anonymous. 1985. Commonwealth Institute of Biological Control Annual Report 1984-1985.

Balcunias, J.K. 1984. The potential for biological control of the submersed aquatic weed, Hydrilla verticillata. Proceedings of the 6 th International Symposium on the Biological Control of Weeds. Vancouver Canada. August 1984 (in press).

Bernhardt, E.A. and J.M. Duniway. 1984. Root and stem rot of parrotfeather (Myriophyllum brasiliense) caused by Pythium carolinianum. Plant Disease 68:999-1003.

Bates, A.L., E.R. Burns, and D.H. Webb. 1985. Eurasian watermilfoil (Myriophyllum spicatum) in the Tennessee Valley: an update on biology and control. Proceedings of the 1st International Symposium on watermilfoil (Myriophyllum spicatum) and related haloragaceae species. Vancouver, British Columbia, 1985 July 23-24. pp. 104-115.

Bayley, S., H. Rabin, and C.H. Southwick. 1968. Recent decline in the distribution and abundance of Eurasian watermilfoil in Chesapeake Bay. Chesapeake Science 9:173-181.

Boyle, T.P. 1979. Response of experimental lentic aquatic ecosystems to suppression of rooted aquatic macrophytes. IN: Aquatic Plants, Lake Management and Ecosystem Consequences of Lake Harvesting. Proc. of the Conference at Madison, 1979 February 14-16.

Center, T.D. and A.0. Jones. 1984. Eichhornia crassipes and Neochetina spp.: The weevil-water hyacinth system. Proc. 6th Internat. Symp. on Biological Control of Weeds. Vancouver, British Columbia, August 1984 (in press).

Conner, J.V., R.P. Gallagher, and M.F. Chatry. 1980. Larval evidence for natural reproduction of the grass carp (Ctenopharyngodon idella) in the lower Mississippii River. IN: Proceedings of the 4th Annual Larval Fish Conference. Oxford, MI. pp. 1-19.

Conway, K.E. 1976. Cerospora rodmanii, a new pathogen of water hyacinth with biological control potential. Canadian Journal of Botany 54:1079-1083. 
Conway, K.E. and T.E. Freeman. 1976. The potential of Cerospora rodmanii as a biological control for water hyacinth. Proc. of the 4 th Internat. Symp. on Biological Control of Weeds.

Cross, D.G. 1969. Aquatic weed control using grass carp. Journal of Fish Biology $1: 27-30$.

Federenko, A.Y. and F.J. Fraser. 1978. A review of the biology of grass carp as a potential weed control agent in British Columbia. Fisheries and Marine Service Technical Report No. 786.

Fernald, M.L. 1950. Gray's manual of botany, 8th ed., New York: American Book Co. 1632 pp.

Frank, P.A. and N. Dechoretz. 1980. Allelopathy in dwarf spikerush (Eleocharis coloradoensis). Weed Science 28:499-505.

Freeman, T.E. 1971. Biological control of aquatic weeds with plant pathogens. Aquatic Botany 3:175-184.

Haag, R.W. 1983. Emergence of seedlings of aquatic macrophytes from lake sediments. Canadian Journal of Botany $61: 148-156$.

Haslam, S.M. 1978. River plants. Cambridge University Press. Cambridge, MA. 396 pp.

Lembi, C.A., B.G. Ritenour, E.M. Iverson, and E.C. Forss. 1978. The effect of vegetation removal of grass carp on water chemistry and phytoplankton in Indiana ponds. Trans. of the Amer. Fish. Soc. 107:161-171.

Leslie, A.J., L.E. Nall, and J.M. Van Dyke. 1983. Effects of vegetation control by grass carp on selected water-quality variables in four Florida lakes. Trans. of the Amer. Fish. Soc. 112:777-787.

Mitzner, W.M. 1978. Evaluation of biological control of nuisance aquatic vegetation by grass carp. Trans. of the Amer. Fish. Soc. 107:135-145.

Moss, E.H. 1983. Flora of Alberta, 2nd edition. J.G. Packer, ed. Toronto: University of Toronto Press. $687 \mathrm{pp}$.

Negonovskaya, I.T. 1981. On the results and prospects of the introduction of phytophagous fishes into waters of the USSR. J. of Ichthyology 20:101-111.

Nichols, S.A. 1974. Mechanical and habitat manipulation for aquatic plant management: a review of techniques. United States Department of Natural Resources Technical Bulletin No. 77.

Ogden, E.C. 1966. Potamogetonaceae. IN: Flora of Texas 1:369-399. 
Ogden, E.C. 1974. Potamogeton in New York. New York State Museum and Science Service Bulletin 423.

Opuszynski, K. 1972. Use of phytophagous fish to control aquatic plants. Aquaculture $1: 61-74$.

Osborne, J.A. 1982. The potential of the hybrid grass carp as a weed control agent. J. of Freshwater Ecology 1:353-360.

Ostrowsky, M.L. and E.R. Zettler. 1986. Chemical defences in aquatic plants. J. of Ecology $74: 279-287$.

Pauley, G.B., G.L. Thomas, S. Bonar, K. Mathews, and A. Unthank. 1985. Overview of the use of triploid grass carp (Ctenopharyngodon idella) as a biocontrol agent for macrophytes in Lake Washington. Weed Science Society of America Abstracts 25:43.

Pierce, B.A. 1983. Grass carp in the United States: a review. Environmental Management 7:151-160.

Prowse, G.A. 1969. The role of cultured pond fish in the control of eutrophication in lakes and dams. Verh. Internat. Verein. Limnol. $17: 714-718$.

Spence, D.H.N. 1975. Light and plant response in freshwater. IN: Light as an Ecological Factor II. C.G. Evans, R. Bainbridge, and 0. Rackham, eds. 16th British Ecological Society Symposium. pp. 93-133.

Spence, D.H.N., T.R. Milburn, M. Ndawala-Senyimba, and E. Roberts. 1971. Fruit biology and germination of two tropical Potamogeton species. New Phytologist. 70:197-212.

Stanley, J.G., W.W. Miley, and D.L. Sutton. 1978. Reproduction requirements and likelihood for naturalization of escaped grass carp in the United States. Trans. of the Amer. Fish. Soc. 107:119-128.

Stroganov, N.S. 1963. The food selectivity of the amur fishes. Akad. Nauk. Turkmensk., SSR. Ashkhabad, pp. 181-191. From Ref. Zh. Biol. (1964) No. 3 T32 (translated from Russian).

Terre11, T.T. 1975. The impact of macrophyte control by the white amur (Ctenopharyngodon idella). Verh. Internat. Verein. Limnol. 19:2510-2514.

Terrel1, J.W. and T.T. Terrel1. 1975. Macrophyte control and food habits of the grass carp in Georgia ponds. Verh. Internat. Verin. Limnol. 19:2515-2520. 
Van Zon, J.C.J. 1977. Grass carp (Ctenopharyngodon idella Val.) in Europe. Aquatic Botany 3:143-155.

Westlake, D.F. 1966. The light climate for plants in rivers. IN: Light as an Ecological Factor. 6th British Columbia Society Symposium. pp. $99-119$.

Westlake, D.F. 1967. Some effects of low-velocity currents on the metabolism of aquatic macrophytes. J. of Exper. Bot. 18:187-205.

Westlake, D.F. 1970. The weight of water-weed in the River Frome. Assoc. of River Authorities Yearbook. pp. 3-12.

Yeo, R.R. 1980. Life history and ecology of dwarf spikerush (Eleocharis coloradoensis). Weed Science 28:263-272.

Yeo, R.R. and R.J. Dow. 1978. Germination of seeds of dwarf spikerush (Eleocharis coloradoensis). Weed Science 26:425-431.

Yeo, R.R. and T.W. Fisher. 1970. Progress and potential for biological control with fish, pathogens, competitive plants and snails. IN: J.T. Holstun, ed. Technical papers of the FAO International Conference on Weed Control. 1970 June 22 - July 01; WSSA, Champaign, Illinois. pp. 450-463.

Yeo, R.R. and J.R. Thurston. 1984. The effect of dwarf spikerush (Eleocharis coloradoensis) on several submersed aquatic weeds. J. of Aquat. Plant Manag. 22:52-56. 

